\title{
Calcium dynamics and chromatin remodelling underlie heterogeneity in prolactin transcription
}

\author{
Claire V Harper¹, Anne V McNamara², David G Spiller², Jayne C Charnock1, Michael R H White² and Julian R E Davis ${ }^{3}$ \\ 'Department of Biology, Edge Hill University, Ormskirk, Lancashire, UK \\ 2Systems Microscopy Centre, Faculty of Biology, Medicine and Health, University of Manchester, Manchester, UK \\ ${ }^{3}$ Endocrine Sciences Research Group, Faculty of Biology, Medicine and Health, University of Manchester, Manchester, UK
}

Correspondence should be addressed to C V Harper: harperc@edgehill.ac.uk

\begin{abstract}
Pituitary cells have been reported to show spontaneous calcium oscillations and dynamic transcription cycles. To study both processes in the same living cell in real time, we used rat pituitary GH3 cells stably expressing human prolactin-luciferase or prolactin-EGFP reporter gene constructs loaded with a fluorescent calcium indicator and measured activity using single-cell time-lapse microscopy. We observed heterogeneity between clonal cells in the calcium activity and prolactin transcription in unstimulated conditions. There was a significant correlation between cells displaying spontaneous calcium spikes and cells showing spontaneous bursts in prolactin expression. Notably, cells showing no basal calcium activity showed low prolactin expression but elicited a significantly greater transcriptional response to BayK8644 compared to cells showing basal calcium activity. This suggested the presence of two subsets of cells within the population at any one time. Fluorescence-activated cell sorting was used to sort cells into two populations based on the expression level of prolactin-EGFP however, the bimodal pattern of expression was restored within $26 \mathrm{~h}$. Chromatin immunoprecipitation showed that these sorted populations were distinct due to the extent of histone acetylation. We suggest that maintenance of a heterogeneous bimodal population is a fundamental characteristic of this cell type and that calcium activation and histone acetylation, at least in part, drive prolactin transcriptional competence.
\end{abstract}
Key Words
- prolactin
- transcription
- calcium
- chromatin
- heterogeneity
- single cell

\section{Introduction}

It is widely reported the that transcription of genes is not a static process and can occur in rapid bursts (with secondminute timescales (Ozbudak et al. 2002, Blake et al. 2003, Raser \& O'Shea 2004, Golding et al. 2005, Raj et al. 2006, Yu et al. 2006, Harper et al. 2011, Fujita et al. 2016)) or longer cycles (with minute-hour timescales (Wijgerde et al. 1995, Zenklusen et al. 2008, Degenhardt et al. 2009, Harper et al. 2011, Suter et al. 2011, Molina et al. 2013)).
In eukaryotic cells this has been studied at the population biochemical level using chromatin immunoprecipitation to measure binding of transcription factors to gene promoters (Metivier et al. 2003, Kangaspeska et al. 2008) or in living single cells using reporter constructs or direct RNA measurements visualise the kinetics of transcription (White et al. 1995, Chubb et al. 2006, Harper et al. 2011, Suter et al. 2011, Molina et al. 2013, Fritzsch et al. 2018). 
Transcription of the hormone prolactin (PRL) has been widely shown to be unstable and pulsatile. The presence and timing of pulses is heterogeneous between cells in both primary pituitary cells (Shorte et al. 2002, Semprini et al. 2009, Harper et al. 2010) and clonal pituitary cell lines (Castano et al. 1996, Takasuka et al. 1998, Semprini et al. 2009, Harper et al. 2010, 2011). We have shown that activation of the human prolactin promoter occurs in long $(\sim 11 \mathrm{~h})$ cycles and we calculated the duration of defined transcriptional 'on', 'off' and 'refractory' periods within this cycle in transcriptionally active cells (Harper et al. 2011). Histone acetylation was shown to be involved in generating these cycles. This supports other studies that suggest that transcription bursts/cycles can be regulated by defined periods of histone modification (Blake et al. 2003, Metivier et al. 2003, Raser \& O'Shea 2004, Metivier et al. 2006, Raj et al. 2006, Kangaspeska et al. 2008).

As well as the role of chromatin modifications on transcriptional heterogeneity, the link between calcium signalling and transcription has been well-reported. Studies from around three decades ago showed that calcium was required for the transcription of prolactin (White et al. 1981, Day \& Maurer 1990, Hoggard et al. 1991). This was followed by pioneering work showing that calcium dynamics are related to downstream transcription (Dolmetsch et al. 1998, Clapham 2007). Primary pituitary cells and pituitary-derived cell lines have been widely shown to exhibit spontaneous oscillations or spikes in intracellular calcium concentration $\left(\left[\mathrm{Ca}^{2+}\right]_{\mathrm{i}}\right)$ (Schlegel et al. 1987, Lewis et al. 1988, Wagner et al. 1993, Villalobos et al. 1998, Shorte et al. 2000, Zimber \& Simasko 2000, Langouche et al. 2001, Van Goor et al. 2001, Romano et al. 2017) and a relationship has been reported between the presence of calcium spikes and prolactin secretion (Law et al. 1989, Charles et al. 1999, Van Goor et al. 2001). An initial link between calcium spikes and prolactin transcription was suggested (Villalobos et al. 2002) but is still not completely understood.

In this study, we focus on two factors that may contribute to the transcriptional heterogeneity of prolactin seen within populations of pituitary cells; calcium dynamics and histone modification.

\section{Materials and methods}

\section{Materials}

Fetal calf serum (FCS) was from Harlan Sera-Lab, Crawley Down, UK, Luciferin was from Bio-Synth, Switzerland. BayK-8644, phenyl methyl sulphonyl fluoride (PMSF) and mammalian protease inhibitor cocktail were from Sigma.
Calcium indicator Fluo-4 and Calcium Orange-AM were from Invitrogen.

\section{Production of stable cell lines and cell culture}

Clonal rat pituitary GH3 cells stably transfected with a 5 kb hPRL-luciferase reporter construct (GH3/prolactin-luc cells) or both the $5 \mathrm{~kb}$ hPRL-luciferase and $5 \mathrm{~kb}$ hPRLdestabilised enhanced green fluorescent protein (d2EGFP) reporter constructs (GH3-DP1) were used as described previously (Takasuka et al. 1998, Harper et al. 2011). Cells were cultured in DMEM containing 10\% v/v FCS and maintained at $37^{\circ} \mathrm{C} 5 \% \mathrm{CO}_{2}$. Cells were maintained in antibiotic to avoid the loss of transgenes.

\section{Fluorescence and luminescence imaging}

GH3/prolactin-luc cells were seeded in $35-\mathrm{mm}$ glass coverslip-based dishes (IWAKI, Japan) $20 \mathrm{~h}$ prior to imaging. Luciferin $(1 \mathrm{mM})$ was added at least $10 \mathrm{~h}$ before the start of the experiment, and the cells were transferred to the stage of a Zeiss Axiovert 200 equipped with an $\mathrm{XL}$ incubator (maintained at $37^{\circ} \mathrm{C}, 5 \% \mathrm{CO}_{2}$, in humid conditions) maintained within a darkened room. Cells were loaded with Fluo- 4 for $30 \mathrm{~min}$ and then time-series imaging was performed using a Fluar x20, 0.75 NA (Zeiss) air objective, with an argon-ion laser at $488 \mathrm{~nm}$. Emitted light was captured through a 505-550 $\mathrm{nm}$ bandpass filter from a $545 \mathrm{~nm}$ dichroic mirror. Calcium recordings were captured every $1 \mathrm{~s}$ for at least $250 \mathrm{~s}$ unless stated otherwise. Data were captured using LSM510 software with consecutive autofocus. The microscope and all light emitting devices were then shut down and luminescence images were captured using a photon-counting charge coupled device camera (Orca II ER, Hamamatsu Photonics, UK). Sequential images, integrated over $30 \mathrm{~min}$, were taken using $4 \times 4$ binning and acquired using Kinetic Imaging software AQM6 (Andor, UK). Bright field images were taken before and after luminescence imaging to allow localization of cells. In the relevant experiments, $0.5 \mu \mathrm{M}$ BayK8644 was added to the dish at around $100 \mathrm{~s}$ during the calcium imaging period.

\section{Analysis of imaging data}

Analysis was carried out using Kinetic Imaging AQM6 software (Andor, UK). Regions of interest were drawn around each single cell, and mean intensity data were collected for both the fluorescence and luminescence time-series. The average instrument dark count (corrected

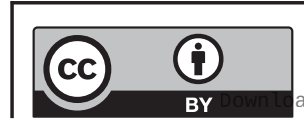

This work is licensed under a Creative Commons Attribution 4.0 International License. 
for the number of pixels being used) was subtracted from the luminescence signal.

Assessment for criteria of luminescence activity was determined as follows. In unstimulated experiments, the luminescence values from each cell were normalised to the population average. A cell that maintained normalised luminescence values lower than the average (1-fold) was termed 'Low'. A cell that maintained normalised luminescence values higher than the average (1-fold) or where the normalised luminescence values varied across the average during the experiment was termed 'High'. In experiments where the cells were stimulated with $0.5 \mu \mathrm{M}$ BayK8644, the luminescence values from each cell were normalised to the average of the first two data points for that particular cell. A response to stimulus (transcription rise) was recorded if the data points for that particular cell increased within $3 \mathrm{~h}$ and reached a 1.5-fold increase within $4 \mathrm{~h}$. Data is presented as mean \pm S.D. and MannWhitney non-parametric tests are used using GraphPad Prism. Classification of active or inactive calcium was assessed manually, where active calcium referred to cells showing calcium spikes within the $250 \mathrm{~s}$ imaging period. Traces were scored blind. Outlying data points were not excluded from the plots.

\section{Flow cytometry and fluorescence activated cell sorting (FACS)}

GH3-DP1 cells were trypsinised and resuspended in PBS at a concentration of $10^{6}$ cells $/ \mathrm{mL}$, before analysisby flow cytometry using a Coulter-Epics Altra flow cytometer.10,000 cells/sample were analysed. Cells were sorted for low and high expression of prolactind2EGFP using FACS with WT GH3 cells used to detect autofluorescence levels. A sample of sorted low and high cells were plated into non-adherent dishes and analysed again after $26 \mathrm{~h}$. For ChIP experiments, at least $1.5 \times 10^{6}$ cells were collected for each of the low, high, unsorted and IgG (unsorted) samples.

\section{ChIP assays and RT-PCR}

Experiments using FACS sorted GH3-DP1 cells $\left(1.5 \times 10^{6}\right.$ per sample) were carried out immediately with the cells in suspension. Formaldehyde was added to each tube at the final concentration of $1 \% \mathrm{v} / \mathrm{v}$ and incubated at room temperature for $15 \mathrm{~min}$. Tubes were kept on ice and then samples were washed twice by centrifugation with PBS supplemented with protease inhibitors $(1 \mathrm{mM}$ PMSF and 1x mammalian protease inhibitor cocktail).
Cells were resuspended into $500 \mu \mathrm{L}$ of PBS with protease inhibitors, centrifuged ( $4 \mathrm{~min}, 500 \boldsymbol{g}$ at $4^{\circ} \mathrm{C}$ ) and the pellet resuspended in $200 \mu \mathrm{L}$ SDS lysis buffer as described previously (Ashall et al. 2009) based on the protocol by Upstate Biotechnology. Immunoprecipitation was carried out using $5 \mu \mathrm{g}$ of either anti-acetylated H3 (Merck Millipore \#06-599), anti-IgG (Merck Millipore \#12-370) or anti-Pit-1 (Santa Cruz \#X-7) antibody. DNA was extracted and amplified by PCR as described previously (Ashall et al. 2009). The primer sequences used were: prolactin Promoter1 left GCAATCTTGAGGAAGAAACTTGA, right AGGCATTCGTTTCCCTTTTC amplifying 347bp of DNA; prolactin Promoter2 left GCATGGGAACTTTAGCATCA, right ATAGCCCCACATTTCCTGTG amplifying 351bp; prolactin Promoter3 left CCTGTGCACATGGACAGAAT, right CCATAGTGGAAGCATTTGGAA amplifying 358bp. PCR products were resolved using agarose gel electrophoresis and densitometry was performed using AQM Advance 6.0 software (Kinetic Imaging, UK). Values were normalised to the unstimulated sample.

\section{Results}

\section{Temporal variation in basal prolactin transcription and calcium patterns in $\mathrm{GH} 3$ cells}

Pulses in prolactin transcription have been reported for many years (Takasuka et al. 1998, Shorte et al. 2002, Semprini et al. 2009, Harper et al. 2010, 2011, Featherstone et al. 2016). In previous work using luminescent and fluorescent microscopy of reporter gene constructs we described the evidence of clearly defined prolactin transcription cycles in single cells, occurring approximately every 11-12 h (Harper et al. 2011). These cycles are observed in clonal GH3 cells and also in transgenic primary pituitary cells (with a longer cycle of $\sim 15 \mathrm{~h}$ ) using reporter constructs of varying promoter length (Harper et al. 2011).

Detailed analysis of prolactin transcriptional activity in GH3 cells containing a $5 \mathrm{~kb}$ prolactin promoterluciferase reporter gene (GH3/prolactin-luc cells) showed that two transcriptional patterns occurred in unstimulated (basal) conditions: $\sim 35 \%$ of cells maintained a relatively even low level of luminescence signal, whereas $\sim 65 \%$ showed high or cycling signal over a recorded $10 \mathrm{~h}$ period of imaging (Fig. 1A and B; 91 cells, six experiments). This analysis is in agreement with our previous study where $\sim 50 \%$ of cells were recorded to show transcription cycles as detected using a binary model of transcription switch times (Harper et al. 2011).

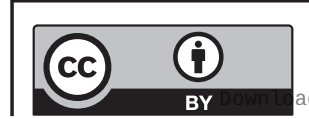

This work is licensed under a Creative Commons Attribution 4.0 International License. ded from Bioscientifica.com at 04/26/2023 10:13:52AM 

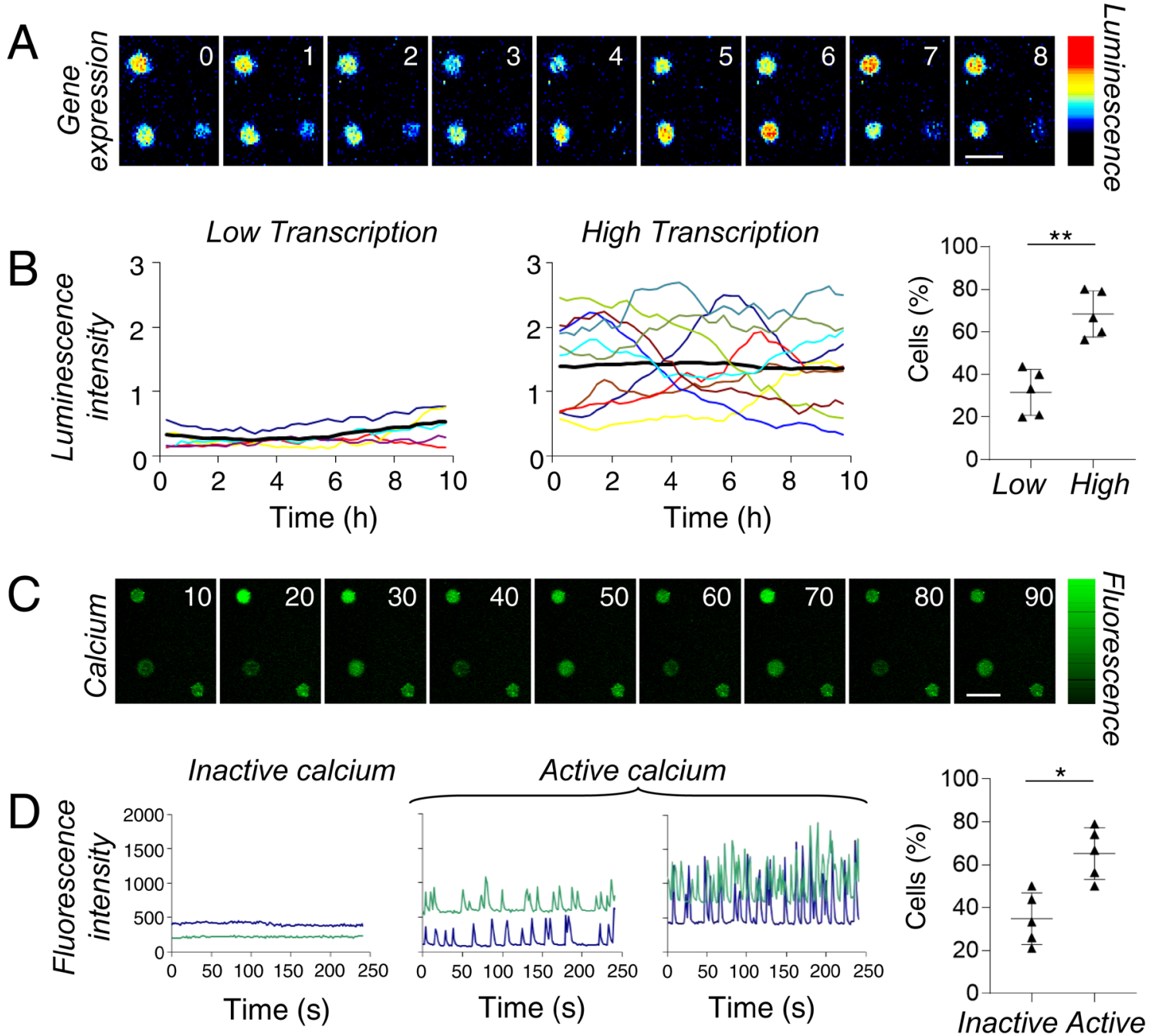

\section{Figure 1}

Temporal heterogeneity in prolactin transcription and calcium profiles between pituitary cells. (A and B) GH3 cells stably expressing a $5 \mathrm{~kb}$ prolactinluciferase reporter gene (GH3/prolactin-luc cells) show 2 transcription patterns in unstimulated conditions; low and high (see Methods for classification), measured using time-lapse luminescence imaging. Each line represents a single cell, thick black line is experiment average. (C and D) GH3/prolactin-luc cells loaded with Fluo-4 show both inactive and active calcium patterns in unstimulated conditions measured using time-lapse fluorescence imaging. Each line represents a single cell. Scatter plots show the proportion of cells defined by each category in unstimulated conditions where each point represents a single experiment (B and $D$ right panels). Bars in image series represent $50 \mu \mathrm{m}$.

GH3 cells, along with other pituitary derived cells, have been widely shown to exhibit spontaneous calcium oscillations (Schlegel et al. 1987, Lewis et al. 1988, Wagner et al. 1993, Villalobos et al. 1998, Shorte et al. 2000, Zimber \& Simasko 2000). Using GH3/prolactin-luc cells loaded with the calcium indicator Fluo-4 to measure changes in intracellular calcium $\left(\left[\mathrm{Ca}^{2+}\right]_{\mathrm{i}}\right)$, we detected spontaneous calcium spikes in around $60 \%$ of cells within a $250 \mathrm{~s}$ period of imaging (Fig. 1C and D). Patterns varied between cells in the timing of the spikes (Fig. 1D). Approximately 30\% of cells showed no calcium spikes within the period of imaging although these cells maintained low basal level of fluorescence above background levels.

\section{Relationship between calcium dynamics and prolactin transcription profiles in single cells}

A key question that arose from these observations was whether there is a relationship between the basal calcium signal and the basal prolactin expression within a particular cell. To answer this, fields of adherent GH3/ prolactin-luc cells were loaded with Fluo-4 to measure $\left[\mathrm{Ca}^{2+}\right]_{\mathrm{i}}$ and fluorescent images were captured every $1 \mathrm{~s}$ for up to $300 \mathrm{~s}$. Then subsequently, luminescence images were captured on the same field of cells to record prolactin promoter activation (Fig. $2 \mathrm{~A}$ ). $\left[\mathrm{Ca}^{2+}\right]_{\mathrm{i}}$ profiles were divided into inactive (those showing no calcium spikes within

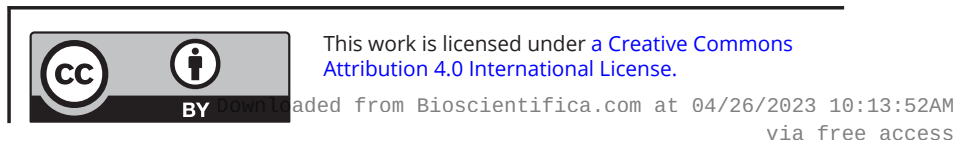




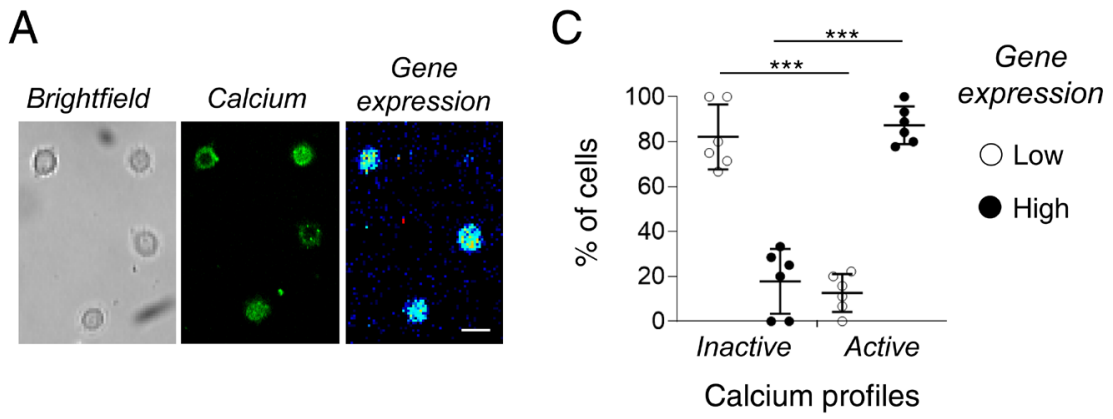

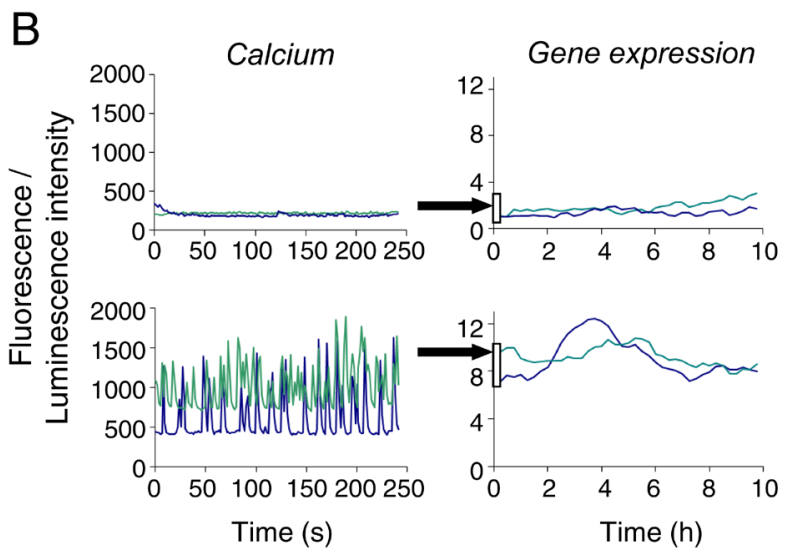

\section{Figure 2}

Relationship between calcium patterns and prolactin transcription in pituitary cells in unstimulated conditions. (A and B) Resting calcium profiles and prolactin transcription were measured sequentially in the same cells. (B) Representative cells showing inactive and active calcium patterns and their subsequent transcriptional patterns. Right panels show mean prolactin transcriptional activity from all cells within an experiment that show inactive or active calcium \pm S.D.. (C) Scatter plot shows the proportion of cells exhibiting low or high prolactin transcription following active or inactive calcium profiles (six experiments, 91 cells; $P<0.01$ ) where each point represents a single experiment. Bar in image represents $20 \mu \mathrm{m}$. the period of imaging) or active (those showing any form of calcium oscillations) (Fig. 2B). Luminescence profiles were divided into two categories: low and high as described in Fig. 1. It was clearly apparent that there was a relationship between the $\left[\mathrm{Ca}^{2+}\right]_{i}$ profile and the transcriptional state of the cells (Fig. 2B and C). 80\% of cells showing no calcium spikes showed low maintained levels of prolactin transcription for at least $10 \mathrm{~h}$ after the calcium recordings were generated. In cells showing active calcium oscillations, over $80 \%$ were displaying high prolactin expression during the following $10 \mathrm{~h}$. This difference was highly significant (Fig. 2C; $P<0.001$ t-test; six experiments, 91 cells). These data suggest that $\left[\mathrm{Ca}^{2+}\right]_{i}$ may prime a cell for transcriptional activation, or that the $\left[\mathrm{Ca}^{2+}\right]_{\mathrm{i}}$ profile determines transcriptional competence of a particular cell.

\section{Relationship between calcium dynamics and the prolactin transcriptional response to stimulus}

Previous research has shown that the transcription of prolactin is cyclical in basal conditions (Harper et al. 2011). These cycles are composed of an active 'on' phase of transcriptional activation (approximately $4 \mathrm{~h}$ ) and an inactive 'off' phase of transcriptional inactivation (approximately $6.5 \mathrm{~h}$ ). The 'off' phase also contains a refractory period of chromatin modelling ( $>3 \mathrm{~h}$ ) where cells cannot respond to stimulus (Harper et al. 2011). Therefore the hypothesis is that cells can only respond immediately to stimulus within the non-refractory period of the 'off' phase. Application of the acute inducer of $\left[\mathrm{Ca}^{2+}\right]_{\mathrm{i}}$ increase, BayK8644, caused a rise in prolactin transcription in $43 \pm 3 \%$ of cells ( $n=5$ experiments, 77 cells) within the first $3 \mathrm{~h}$ following treatment. This supports the above hypothesis, in that not all cells are in a state in which they can be activated immediately. To test whether the transcriptional response to stimulus varied depending on the preceding basal $\left[\mathrm{Ca}^{2+}\right]_{i}$ profile of the cell, GH3/prolactin-luc cells were labelled with fluo-4 and imaged for changes in $\left[\mathrm{Ca}^{2+}\right]_{\mathrm{i}}$, during which $0.5 \mu \mathrm{M}$ BayK8466 was applied to the dish. Prolactin transcription was then measured in the same field of cells for up to $10 \mathrm{~h}$.

Although BayK8644 induced an increase in $\left[\mathrm{Ca}^{2+}\right]_{\mathrm{i}}$ in most cells, there was a surprising relationship between the basal $\left[\mathrm{Ca}^{2+}\right]_{\mathrm{i}}$ profile of a cell before stimulus and its transcriptional response to the stimulus (Fig. 3). The majority of cells where no basal oscillations in $\left[\mathrm{Ca}^{2+}\right]_{i}$ were recorded prior to stimulus addition responded with a significant transcriptional rise following application of the stimulus (Fig. 3A, C and D; for determination of a significant transcriptional rise see the Materials and methods section). In cells showing basal oscillations in $\left[\mathrm{Ca}^{2+}\right]_{i}$ before addition of the stimulus, few responded with a stimulus-induced transcriptional rise (Fig. 3B, C and

This work is licensed under a Creative Commons Attribution 4.0 International License. 
A
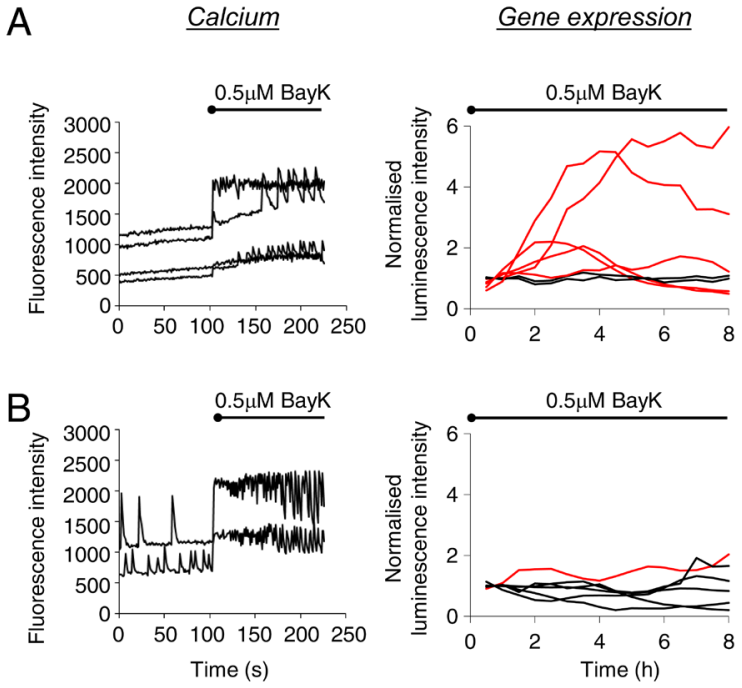
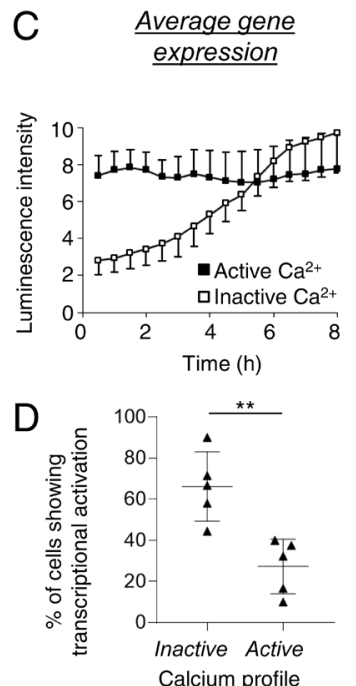

Figure 3

Relationship between calcium patterns and prolactin transcription in pituitary cells in stimulated conditions. (A and B) Calcium profiles and subsequent prolactin transcriptional response patterns following treatment with 0.5 $\mu \mathrm{M}$ BayK8644. The calcium and transcriptional responses to $0.5 \mu \mathrm{M}$ BayK8644 were measured in cells that showed initial (pre-stimulus) active (A) or inactive (B) resting calcium profiles. Red gene expression traces show a response and black traces show no response to the stimulus (see methods for classification). (C) Mean single cell transcriptional response patterns from cells showing initial active or inactive calcium profiles. Points show mean \pm S.D. (D) The proportion of cells showing transcriptional response to stimulus following initial active or inactive calcium profiles, mean \pm s.D. (five experiments, 77 cells, $P<0.01$ ) where each point represents a single experiment.
D). This difference was highly significant (Fig. 3D; $67 \pm$ $\%$ in inactive cells compared to $26 \pm 8 \%$ in active cells; $P<0.01, t$-test, five experiments, 77 cells).

These data, taken together with those of Fig. 2, suggest that cells showing basal oscillations in $\left[\mathrm{Ca}^{2+}\right]_{\mathrm{i}}$ are the prolactin-transcriptionally active population but are less able to respond immediately to acute application of stimulus. In contrast, cells showing no basal $\left[\mathrm{Ca}^{2+}\right]_{\mathrm{i}}$ oscillations are transcriptionally dormant (within our experimental detection range) but poised to generate an immediate transcriptional response to the calcium stimulus.

\section{Temporal heterogeneity in prolactin transcription in clonal GH3 cells}

Several reports using reporter gene constructs have shown that clonal and primary pituitary cells display heterogeneity in the levels of human prolactin expression (Castano et al. 1996, Takasuka et al. 1998, Shorte et al. 2002, Semprini et al. 2009, Harper et al. 2010, 2011, Featherstone et al. 2011). To estimate the extent of basal cellular heterogeneity, GH3 cells stably expressing prolactin-d2EGFP were analysed using flow cytometry (Fig. 4A). WT GH3 cells were used as an auto-fluorescence control. The reporter gene fluorescence intensity within the unstimulated cell population varied over two orders of magnitude indicating cellular variation in the expression of prolactin (Fig. 4B). The distribution of the cell population was bimodal suggesting that there may be two dominant groups of cells, high prolactin expression and low prolactin expression. We have previously shown that cells switch from a transcription 'on' state to an 'off' state in unstimulated conditions over the duration of several hours (Harper et al. 2011) so that these data support that view. Using fluorescence-activated cell sorting, the cells were sorted into two populations; 'Low' ( $\sim 30 \%$ of the total population) and 'High' ( $70 \%$ of the total population). The fluorescence levels of these sorted populations were re-analysed after 1 and $26 \mathrm{~h}$ to measure the dynamic responsiveness of individual cells (Fig. 4A, C, D and E). After $26 \mathrm{~h}$, the High cell population maintained a similar distribution. But in contrast, the Low population of cells had changed, reverting back into the bimodal distribution shown in the unsorted population (Fig. 4D and E). This clearly shows that the fluorescence expression level of the cells is transient, with cells capable of switching between low and high transcriptional states.

\section{Relationship between prolactin transcription and histone modification status}

We have previously suggested that the cycles in prolactin transcription are modulated by histone acetylation, in particular proposing that the refractory period of transcriptional activation may be the result of a period of closed chromatin (Harper et al. 2011). To determine in more detail whether the extent of histone acetylation changes during prolactin transcription cycles, GH3-DP1 cells were sorted into populations of Low and High basal prolactin expression by FACS as described above (Fig. 4A). Chromatin immunoprecipitation (ChIP) was immediately performed on these cell populations, using unsorted GH3-DP1 cells as a comparison. Three sites were selected within the human prolactin promoter to measure the extent of acetylated histone H3 (Ac-H3) bound to the

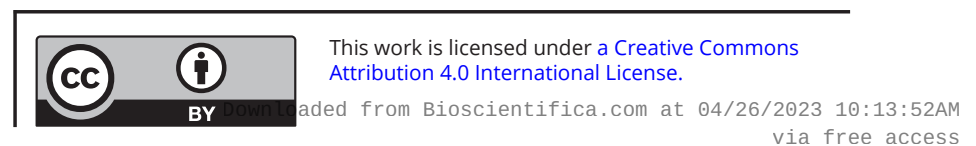


A
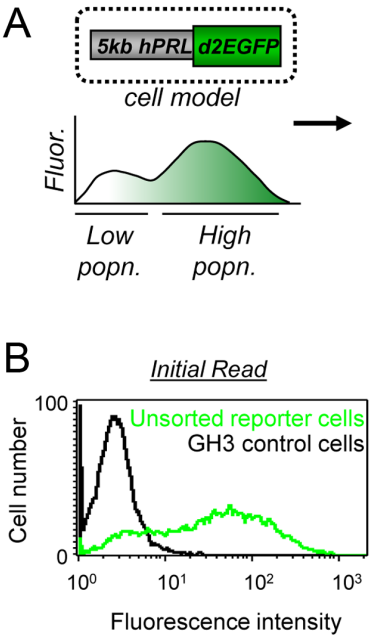
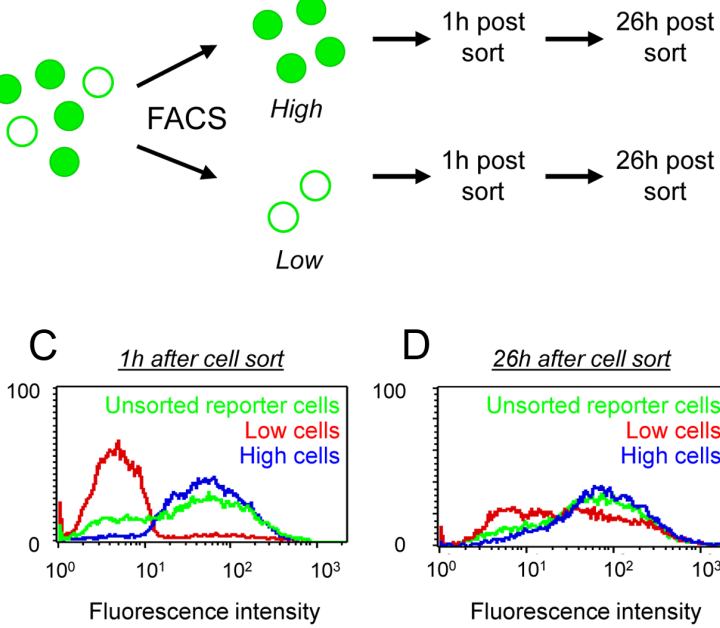

D $26 h$ after cell sort

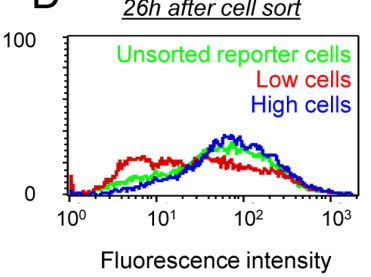

\begin{tabular}{l||cc|cc}
\multicolumn{2}{c||}{$E$} & \multicolumn{2}{c}{$1 h$} & \multicolumn{2}{c}{$26 h$} \\
\cline { 3 - 5 } & Low & High & Low & High \\
\hline \hline GH3 control & $98.5 \pm 1 \%$ & $1.5 \pm 1 \%$ & $98 \pm 1 \%$ & $2 \pm 1 \%$ \\
Unsorted & $28.5 \pm 4 \%$ & $71.5 \pm 4 \%$ & $25.5 \pm 2 \%$ & $74.5 \pm 1 \%$ \\
Low & $86 \pm 3 \%$ & $14 \pm 3 \%$ & $32 \pm 4 \%$ & $68 \pm 4 \%$ \\
High & $6.5 \pm 2 \%$ & $93.5 \pm 2 \%$ & $7 \pm 1 \%$ & $93 \pm 1 \%$
\end{tabular}

\section{Figure 4}

Maintenance of heterogeneity between clonal cells. (A) Model showing protocol. GH3 cells stably expressing a $5 \mathrm{~kb}$ prolactin-destabilised EGFP reporter gene (GH3-DP1 cells) were sorted for basal prolactin expression level using FACS. The fluorescence of these sorted cell populations was then measured after $1 \mathrm{~h}$ and $26 \mathrm{~h}$. (B) Variation in basal prolactin gene expression in clonal GH3-DP1 cells (green trace) compared to the WT GH3 cell line (black trace). Measurement of fluorescence levels in High (blue trace) and Low (red trace) expressing GH3-DP1 cells following FACS after $1 \mathrm{~h}$ (C) and $26 \mathrm{~h}$ (D). Data from one representative experiment are shown. (E) Table showing the proportion of cells \pm S.D. classified as High or Low prolactin expression $1 \mathrm{~h}$ and $26 \mathrm{~h}$ post-FACS in GH3 cells (control), unsorted cells, low expressing cell population and high expressing cell population (three experiments).
DNA (Fig. 5A). The localisation of these sites was based on the prior knowledge that there are enhancer regions within this promoter (Peers et al. 1990, Van De Weerdt et al. 2000). Primer 1 was in the proximal enhancer region, primer 2 was $2 \mathrm{~kb}$ upstream and primer 3 was in the distal enhancer region $4 \mathrm{~kb}$ upstream. All three regions contained Pit-1 binding sites, the critical transcription factor for prolactin expression (Fig. 5A). In the Low prolactin transcription cell population (also containing cells in a transcriptional refractory phase (Harper et al. 2011)) there was a decrease in Ac-H3 bound to all three sites in the human prolactin promoter when compared to transcriptionally High population of cells (Fig. 5B and C). This implies that the chromatin was more accessible during periods of high prolactin transcription. In contrast, the extent of Pit-1 binding remained consistent across the
A

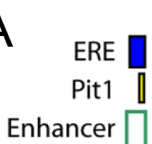

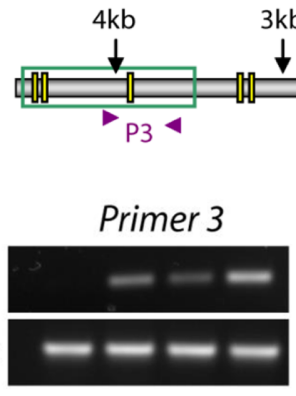

IgG Un Low High

B

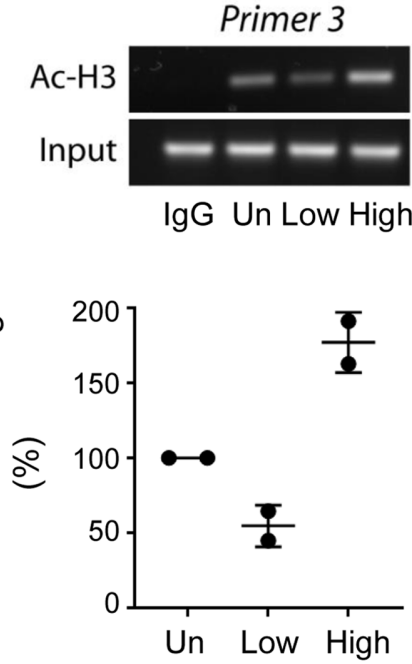

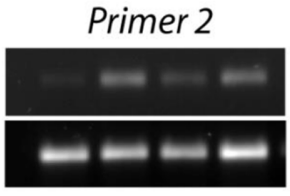

IgG Un Low High

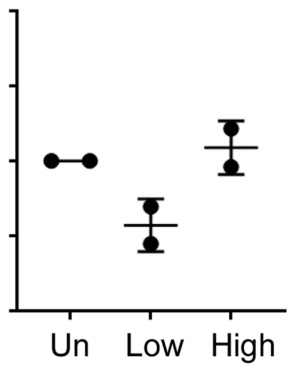

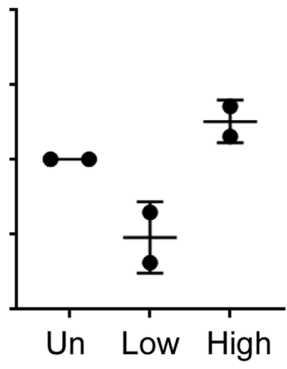

\section{Figure 5}

Relationship between level of prolactin transcription and chromatin status at the prolactin promoter. (A) Location of target sites for amplification within the proximal prolactin promoter (designated P1, P2 and P3). GH3-DP1 cells expressing prolactin-eGFP were sorted by level of basal prolactin transcription using FACs (Fig. 4). Cells were classified as unsorted (Un), low transcription (Low) and high transcription (High). ( $B$ and $C$ ) The level of Acetylated histone $\mathrm{H} 3$ was measured using ChIP across the three amplification sites (two experiments, mean \pm s.D.). https://jme.bioscientifica.com https://doi.org/10.1530/JME-20-0223 (c) 2021 The authors Published by Bioscientifica Ltd. Printed in Great Britain

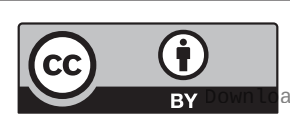

This work is licensed under a Creative Commons Attribution 4.0 International License. 
low and high prolactin transcriptional cell populations (Supplementary Fig. 1, see section on supplementary materials given at the end of this article), suggesting that Pit-1 remains bound to the DNA during cycles of prolactin transcription in unstimulated conditions and that the cycles in transcription are not due to cycles in Pit-1 binding.

\section{Discussion}

Cycles in prolactin gene expression have been wellreported in the literature (Shorte et al. 2002, Semprini et al. 2009, Harper et al. 2010, 2011, Featherstone et al. 2016) but here we add new mechanistic information about how these cycles may occur. We show that within a clonal population of resting GH3 cells there is variability in the extent of prolactin expression, calcium dynamics and histone acetylation. The resting calcium dynamics appear to determine the transcriptional competence of the cell (i.e. whether a cell is transcriptionally active or can respond to a stimulus). Within the population of GH3 cells there were two distinct subpopulations: (1) cells showing inactive calcium, low prolactin transcription and decreased Ac-H3 binding on the human prolactin promoter (closed chromatin) and (2) cells showing active calcium, high or cycling prolactin transcription and increased Ac-H3 binding on the prolactin promoter (open chromatin) (Fig. 6A). In contrast, the levels of Pit-1 binding to the human prolactin promoter were not related to the degree of prolactin transcription implying that Pit-1 may remain bound to the DNA and be controlled by post-translational modifications (Demarco et al. 2006).

Work from other groups has suggested a role for calcium signalling in the epigenetic regulation of genes. Sharma and colleagues described a mechanism where increased calcium levels led to changes in chromatin modifications and regulation of gene expression at the level of alternative splicing in cardiomyocytes (Sharma et al. 2014) and Raynal et al. interestingly showed the potential importance of calcium signalling on the reversal of epigenetic silencing of tumour suppressor genes (Raynal et al. 2016). In light of this work, further study should be carried out to determine whether the levels of $\left[\mathrm{Ca}^{2+}\right]_{\mathrm{i}}$ set up a cell for transcriptional activation by mechanisms involving chromatin remodelling. Following our earlier work, where we showed that the histone deacetylase inhibitor Trichostatin A affected basal prolactin expression dynamics (Harper et al. 2011), it would be interesting to determine whether the relationship between calcium and
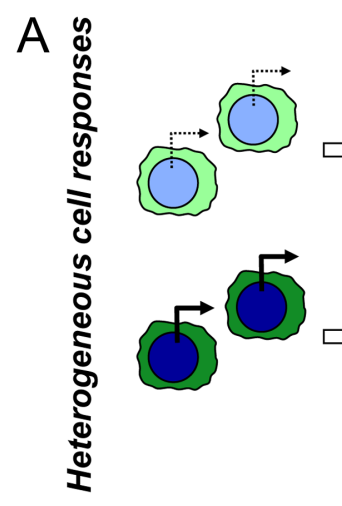

Calcium

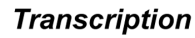

$\mathrm{B}$

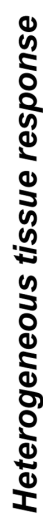

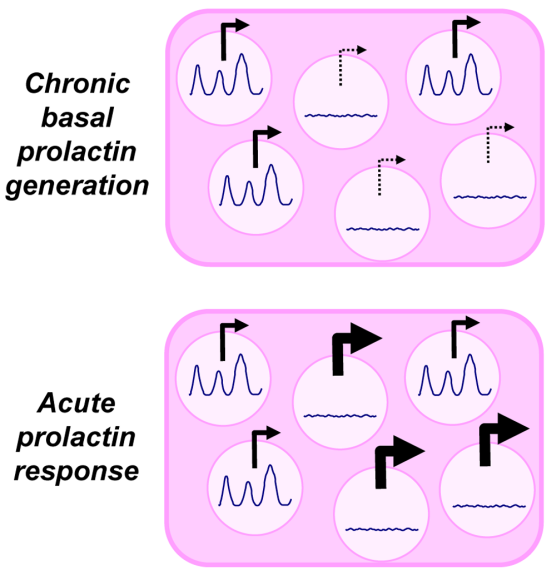

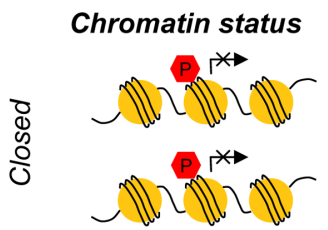

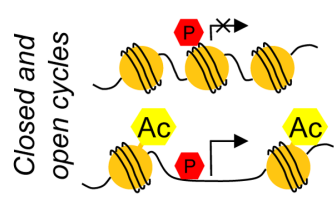

https://jme.bioscientifica.com https://doi.org/10.1530/JME-20-0223 (c) 2021 The authors Published by Bioscientifica Ltd. Printed in Great Britain

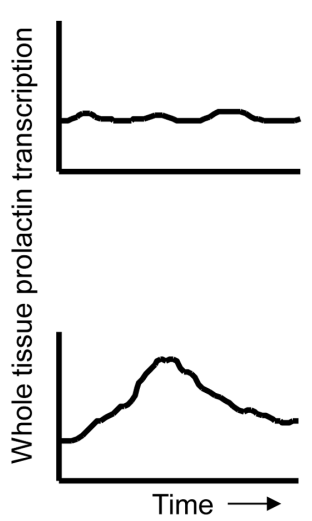

\section{Figure 6}

Schematic showing cellular heterogeneity in single pituitary cells and pituitary cells within a tissue. (A) Relationship between calcium profile, prolactin transcription and chromatin status in single pituitary cells. (B, top panel) In basal conditions a subset of cells within pituitary tissue is expressing prolactin at any one time, resulting in low, chronic basal expression of prolactin across the tissue. (B, bottom panel) In stimulated conditions, the cells showing low prolactin transcription within the tissue respond to the stimulus, mounting an acute surge of prolactin expression. 
transcriptional activity can be modulated by disrupting chromatin remodelling.

Maintenance of cellular heterogeneity has been reported to be functionally advantageous at the population level (Paszek et al. 2010). We hypothesise that maintenance of a heterogeneous cell population is of innate importance in these hormone producing cells and that the variability in transcription correlated with variability in the calcium status and histone modification status of the cells. Heterogeneity within the cell population was disrupted by separating into two cell populations based on the level of prolactin gene expression. The observation that the low cell population reverted back to having the same transcriptional distribution as the unsorted population within $26 \mathrm{~h}$ implies that cells are not constrained to one pattern of expression (high or low), and can switch between states, potentially dependent on the surrounding cells. This observation of maintenance to a steady-state population distribution supports other reports in other clonal cell lines (Sigal et al. 2006, Pilbrough et al. 2009) although this appears to occur more rapidly in our cells.

The maintenance of a heterogeneous cell population may be important within pituitary tissue, whereby at any fixed time there is a subset of cells expressing prolactin to enable low, chronic basal hormone production (transcriptionally high and cycling cells) but there is also a subset of cells which are ready to mount a response to external stimuli to enable acute hormone production (transcriptionally low cells, Fig. 6B). The observation that an external stimulus (BayK8644) induced prolactin transcription in significantly more calcium inactive cells compared to calcium active cells provided further evidence that there are two cellular sub-populations and supports the idea that it is the inactive cells that are capable of mounting a rapid rise in prolactin transcription. Using similar simultaneous measurements of calcium and rat PRL-luciferase expression in primary rat mammotropes, Villalobos and colleagues (Villalobos et al. 2002) showed that the extent of transcriptional response to TSH-releasing hormone was dependent on the resting transcriptional status and the profile of $\left[\mathrm{Ca}^{2+}\right]_{i}$ response. Whether our observations occur in primary rat pituitary cells have not been determined in this study. Heterogeneity in $\left[\mathrm{Ca}^{2+}\right]_{i}$ has also recently been reported in corticotroph cell populations following treatment with the hypothalamic secretagogues corticotrophinreleasing hormone and arginine vasopressin (Romano et al. 2017). Our results, together with the findings from these other studies, suggest that cell variability may be mechanistically important at the population level within endocrine tissues, enabling graded responses to varying stimulation levels through changes in cell recruitment. Whether there is a relationship between $\left[\mathrm{Ca}^{2+}\right]_{i}$, prolactin transcription and secretion, namely whether cells with inactive calcium and low transcription are non-secreting, remains to be shown.

In summary we report, for the first time, a significant relationship between the basal calcium dynamics and prolactin transcription in single living GH3 rat pituitary cells. We also show that variability in the extent of histone acetylation on the prolactin promoter determines basal prolactin transcription. It remains to be studied how the heterogeneity within the pituitary cell population is maintained and whether these cells are capable of detecting the status of surrounding cells (through paracrine signalling) and adjusting their role accordingly.

\section{Supplementary materials}

This is linked to the online version of the paper at https://doi.org/10.1530/ JME-20-0223.

\section{Declaration of interest}

The authors declare that there is no conflict of interest that could be perceived as prejudicing the impartiality of the research reported.

\section{Funding}

This work was supported by the Wellcome Trust (Programme Grant \#091688 to J R E D and M R H W). C H was funded by The Professor John Glover Postdoctoral Memorial Fellowship.

\section{Author contribution statement}

$\mathrm{C} \mathrm{VH}$ designed, performed and analysed the research and wrote the manuscript. A V M led the FACS experiments and advised on experiments throughout the study. J C advised on the manuscript. D G S was involved in discussions on the analysis and the manuscript, and managed the Systems Microscopy Centre. M R H W directed the Systems Microscopy Centre and was involved in critical discussions of the work. J R E D advised throughout the study and assisted with writing the manuscript.

\section{Acknowledgements}

Thanks to Paul Le Tissier and James Bagnall for critical discussion on the analysis and the manuscript. Hamamatsu Photonics and Carl Zeiss Limited provided technical support.

\section{References}

Ashall L, Horton CA, Nelson DE, Paszek P, Harper CV, Sillitoe K, Ryan S, Spiller DG, Unitt JF, Broomhead DS, et al. 2009 Pulsatile stimulation

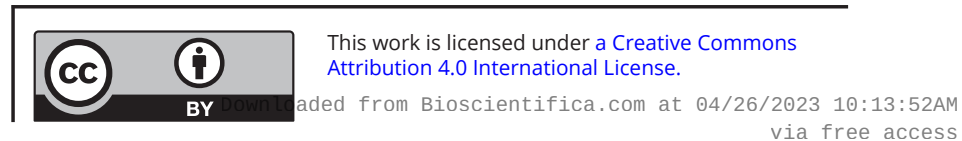


determines timing and specificity of NF-kappaB-dependent transcription. Science 324 242-246. (https://doi.org/10.1126/ science.1164860)

Blake WJ, KAErn M, Cantor CR \& Collins JJ 2003 Noise in eukaryotic gene expression. Nature 422 633-637. (https://doi.org/10.1038/ nature01546)

Castano JP, Kineman RD \& Frawley LS 1996 Dynamic monitoring and quantification of gene expression in single, living cells: a molecular basis for secretory cell heterogeneity. Molecular Endocrinology 10 599-605. (https://doi.org/10.1210/mend.10.5.8732690)

Charles AC, Piros ET, Evans CJ \& Hales TG 1999 L-type Ca2+ channels and $\mathrm{K}+$ channels specifically modulate the frequency and amplitude of spontaneous $\mathrm{Ca} 2+$ oscillations and have distinct roles in prolactin release in GH3 cells. Journal of Biological Chemistry 274 7508-7515. (https://doi.org/10.1074/jbc.274.11.7508)

Chubb JR, Trcek T, Shenoy SM \& Singer RH 2006 Transcriptional pulsing of a developmental gene. Current Biology 16 1018-1025. (https://doi. org/10.1016/j.cub.2006.03.092)

Clapham DE 2007 Calcium signaling. Cell 131 1047-1058. (https://doi. org/10.1016/j.cell.2007.11.028)

Day RN \& Maurer RA 1990 Pituitary calcium channel modulation and regulation of prolactin gene expression. Molecular Endocrinology 4 736-742. (https://doi.org/10.1210/mend-4-5-736)

Degenhardt T, Rybakova KN, Tomaszewska A, Mone MJ, Westerhoff HV, Bruggeman FJ \& Carlberg C 2009 Population-level transcription cycles derive from stochastic timing of single-cell transcription. Cell 138 489-501. (https://doi.org/10.1016/j. cell.2009.05.029)

Demarco IA, Voss TC, Booker CF \& Day RN 2006 Dynamic interactions between Pit-1 and C/EBPalpha in the pituitary cell nucleus. Molecular and Cellular Biology 26 8087-8098. (https://doi.org/10.1128/ MCB.02410-05)

Dolmetsch RE, Xu K \& Lewis RS 1998 Calcium oscillations increase the efficiency and specificity of gene expression. Nature 392 933-936. (https://doi.org/10.1038/31960)

Featherstone K, Harper CV, McNamara A, Semprini S, Spiller DG, McNeilly J, McNeilly AS, Mullins JJ, White MRH \& Davis JRE 2011 Pulsatile patterns of pituitary hormone gene expression change during development. Journal of Cell Science 124 3484-3491. (https:// doi.org/10.1242/jcs.088500)

Featherstone K, Hey K, Momiji H, McNamara AV, Patist AL, Woodburn J, Spiller DG, Christian HC, McNeilly AS, Mullins JJ, et al. 2016 Spatially coordinated dynamic gene transcription in living pituitary tissue. eLife 5 e08494. (https://doi.org/10.7554/eLife.08494)

Fritzsch C, Baumgartner S, Kuban M, Steinshorn D, Reid G \& Legewie S 2018 Estrogen-dependent control and cell-to-cell variability of transcriptional bursting. Molecular Systems Biology 14 e7678. (https:// doi.org/10.15252/msb.20177678)

Fujita K, Iwaki M \& Yanagida T 2016 Transcriptional bursting is intrinsically caused by interplay between RNA polymerases on DNA. Nature Communications 7 13788. (https://doi.org/10.1038/ ncomms13788)

Golding I, Paulsson J, Zawilski SM \& Cox EC 2005 Real-time kinetics of gene activity in individual bacteria. Cell 123 1025-1036. (https://doi. org/10.1016/j.cell.2005.09.031)

Harper CV, Featherstone K, Semprini S, Friedrichsen S, McNeilly J, Paszek P, Spiller DG, McNeilly AS, Mullins JJ, Davis JR, et al. 2010 Dynamic organisation of prolactin gene expression in living pituitary tissue. Journal of Cell Science 123 424-430. (https://doi. org/10.1242/jcs.060434)

Harper CV, Finkenstadt B, Woodcock DJ, Friedrichsen S, Semprini S, Ashall L, Spiller DG, Mullins JJ, Rand DA, Davis JRE, et al. 2011 Dynamic analysis of stochastic transcription cycles. PLoS Biology 9 e1000607. (https://doi.org/10.1371/journal.pbio.1000607)

Hoggard N, Davis JR, Berwaer M, Monget P, Peers B, Belayew A \& Martial JA 1991 Pit-1 binding sequences permit calcium regulation Printed in Great Britain of human prolactin gene expression. Molecular Endocrinology 5 1748-1754. (https://doi.org/10.1210/mend-5-11-1748)

Kangaspeska S, Stride B, Metivier R, Polycarpou-Schwarz M, Ibberson D, Carmouche RP, Benes V, Gannon F \& Reid G 2008 Transient cyclical methylation of promoter DNA. Nature 452 112-U114. (https://doi. org/10.1038/nature06640)

Langouche L, Roudbaraki M, Pals K \& Denef C 2001 Stimulation of intracellular free calcium in GH3 cells by gamma3-melanocytestimulating hormone. Involvement of a novel melanocortin receptor? Endocrinology 142 257-266. (https://doi.org/10.1210/ endo.142.1.7878)

Law GJ, Pachter JA \& Dannies PS 1989 Ability of repetitive Ca2+ spikes to stimulate prolactin release is frequency dependent. Biochemical and Biophysical Research Communications 158 811-816. (https://doi. org/10.1016/0006-291x(89)92794-0)

Lewis DL, Goodman MB, John PASt \& Barker JL 1988 Calcium currents and fura-2 signals in fluorescence-activated cell sorted lactotrophs and somatotrophs of rat anterior pituitary. Endocrinology 123 611-621. (https://doi.org/10.1210/endo-123-1-611)

Metivier R, Penot G, Hubner MR, Reid G, Brand H, Kos M \& Gannon F 2003 Estrogen receptor-alpha directs ordered, cyclical, and combinatorial recruitment of cofactors on a natural target promoter. Cell 115 751-763. (https://doi.org/10.1016/s00928674(03)00934-6)

Metivier R, Reid G \& Gannon F 2006 Transcription in four dimensions: nuclear receptor-directed initiation of gene expression. EMBO Reports 7 161-167. (https://doi.org/10.1038/sj.embor.7400626)

Molina N, Suter DM, Cannavo R, Zoller B, Gotic I \& Naef F 2013 Stimulus-induced modulation of transcriptional bursting in a single mammalian gene. PNAS 110 20563-20568. (https://doi.org/10.1073/ pnas.1312310110)

Ozbudak EM, Thattai M, Kurtser I, Grossman AD \& van Oudenaarden A 2002 Regulation of noise in the expression of a single gene. Nature Genetics 31 69-73. (https://doi.org/10.1038/ng869)

Paszek P, Ryan S, Ashall L, Sillitoe K, Harper CV, Spiller DG, Rand DA \& White MR 2010 Population robustness arising from cellular heterogeneity. PNAS 107 11644-11649. (https://doi.org/10.1073/ pnas.0913798107)

Peers B, Voz ML, Monget P, Mathy-Hartert M, Berwaer M, Belayew A \& Martial JA 1990 Regulatory elements controlling pituitary-specific expression of the human prolactin gene. Molecular and Cellular Biology 10 4690-4700. (https://doi.org/10.1128/mcb.10.9.4690)

Pilbrough W, Munro TP \& Gray P 2009 Intraclonal protein expression heterogeneity in recombinant CHO cells. PLOS ONE 4 e8432. (https://doi.org/10.1371/journal.pone.0008432)

Raj A, Peskin CS, Tranchina D, Vargas DY \& Tyagi S 2006 Stochastic mRNA synthesis in mammalian cells. PLoS Biology 4 e309. (https:// doi.org/10.1371/journal.pbio.0040309)

Raser JM \& O'Shea EK 2004 Control of stochasticity in eukaryotic gene expression. Science 304 1811-1814. (https://doi.org/10.1126/ science.1098641)

Raynal NJ, Lee JT, Wang Y, Beaudry A, Madireddi P, Garriga J, Malouf GG, Dumont S, Dettman EJ, Gharibyan V, et al. 2016 Targeting calcium signaling induces epigenetic reactivation of tumor suppressor genes in cancer. Cancer Research 76 1494-1505. (https:// doi.org/10.1158/0008-5472.CAN-14-2391)

Romano N, McClafferty H, Walker JJ, Le Tissier P \& Shipston MJ 2017 Heterogeneity of calcium responses to secretagogues in corticotrophs from male rats. Endocrinology 158 1849-1858. (https://doi. org/10.1210/en.2017-00107)

Schlegel W, Winiger BP, Mollard P, Vacher P, Wuarin F, Zahnd GR, Wollheim CB \& Dufy B 1987 Oscillations of cytosolic Ca2+ in pituitary cells due to action potentials. Nature 329 719-721. (https:// doi.org/10.1038/329719a0)

Semprini S, Friedrichsen S, Harper CV, McNeilly JR, Adamson AD, Spiller DG, Kotelevtseva N, Brooker G, Brownstein DG, McNeilly AS,

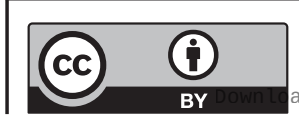

This work is licensed under a Creative Commons Attribution 4.0 International License. ded from Bioscientifica.com at 04/26/2023 10:13:52AM 
et al. 2009 Real-time visualization of human prolactin alternate promoter usage in vivo using a double-transgenic rat model. Molecular Endocrinology 23 529-538. (https://doi.org/10.1210/ me.2008-0399)

Sharma A, Nguyen H, Geng C, Hinman MN, Luo G \& Lou H 2014 Calcium-mediated histone modifications regulate alternative splicing in cardiomyocytes. PNAS 111 E4920-E4928. (https://doi. org/10.1073/pnas.1408964111)

Shorte SL, Faught WJ \& Frawley LS 2000 Spontaneous calcium oscillatory patterns in mammotropes display non-random dynamics. Cell Calcium 28 171-179. (https://doi.org/10.1054/ ceca.2000.0147)

Shorte SL, Leclerc GM, Vazquez-Martinez R, Leaumont DC, Faught WJ, Frawley LS \& Boockfor FR 2002 PRL gene expression in individual living mammotropes displays distinct functional pulses that oscillate in a noncircadian temporal pattern. Endocrinology 143 1126-1133. (https://doi.org/10.1210/endo.143.3.8682)

Sigal A, Milo R, Cohen A, Geva-Zatorsky N, Klein Y, Liron Y, Rosenfeld N, Danon T, Perzov N \& Alon U 2006 Variability and memory of protein levels in human cells. Nature $\mathbf{4 4 4}$ 643-646. (https://doi.org/10.1038/nature05316)

Suter DM, Molina N, Gatfield D, Schneider K, Schibler U \& Naef F 2011 Mammalian genes are transcribed with widely different bursting kinetics. Science 332 472-474. (https://doi.org/10.1126/ science.1198817)

Takasuka N, White MRH, Wood CD, Robertson WR \& Davis JRE 1998 Dynamic changes in prolactin promoter activation in individual living lactotrophic cells. Endocrinology 139 1361-1368. (https://doi. org/10.1210/endo.139.3.5826)

Van De Weerdt C, Peers B, Belayew A, Martial JA \& Muller M 2000 Far upstream sequences regulate the human prolactin promoter transcription. Neuroendocrinology 71 124-137. (https://doi. org/10.1159/000054528)

Van Goor F, Zivadinovic D, Martinez-Fuentes AJ \& Stojilkovic SS 2001 Dependence of pituitary hormone secretion on the pattern of spontaneous voltage-gated calcium influx. Cell type-specific action potential secretion coupling. Journal of Biological Chemistry 276 33840-33846. (https://doi.org/10.1074/jbc.M105386200)

Villalobos C, Faught WJ \& Frawley LS 1998 Dynamic changes in spontaneous intracellular free calcium oscillations and their relationship to prolactin gene expression in single, primary mammotropes. Molecular Endocrinology 12 87-95. (https://doi. org/10.1210/mend.12.1.0055)

Villalobos C, Nunez L, Faught WJ, Leaumont DC, Boockfor FR \& Frawley LS 2002 Calcium dynamics and resting transcriptional activity regulates prolactin gene expression. Endocrinology $\mathbf{1 4 3}$ 3548-3554. (https://doi.org/10.1210/en.2002-220266)

Wagner KA, Yacono PW, Golan DE \& Tashjian Jr AH 1993 Mechanism of spontaneous intracellular calcium fluctuations in single GH4C1 rat pituitary cells. Biochemical Journal 292 175-182. (https://doi. org/10.1042/bj2920175)

White BA, Bauerle LR \& Bancroft FC 1981 Calcium specifically stimulates prolactin synthesis and messenger RNA sequences in GH3 cells. Journal of Biological Chemistry 256 5942-5945.

White MRH, Masuko M, Amet L, Elliott G, Braddock M, Kingsman AJ \& Kingsman SM 1995 Real-time analysis of the transcriptional regulation of HIV and HCMV promoters in single mammalian-cells. Journal of Cell Science 108 441-455.

Wijgerde M, Grosveld F \& Fraser P 1995 Transcription complex stability and chromatin dynamics in-vivo. Nature 377 209-213. (https://doi. org/10.1038/377209a0)

Yu J, Xiao J, Ren X, Lao K \& Xie XS 2006 Probing gene expression in live cells, one protein molecule at a time. Science 311 1600-1603. (https://doi.org/10.1126/science.1119623)

Zenklusen D, Larson DR \& Singer RH 2008 Single-RNA counting reveals alternative modes of gene expression in yeast. Nature Structural and Molecular Biology 15 1263-1271. (https://doi.org/10.1038/nsmb.1514)

Zimber MP \& Simasko SM 2000 Recruitment of calcium from intracellular stores does not occur during the expression of large spontaneous calcium oscillations in $\mathrm{GH}(3)$ cells and lactotropic cells in primary culture. Neuroendocrinology $\mathbf{7 2}$ 242-251. (https://doi. org/10.1159/000054593

Received in final form 17 September 2020

Accepted 20 October 2020

Accepted Manuscript published online 20 October 2020 (c) 2021 The authors Published by Bioscientifica Ltd. Printed in Great Britain

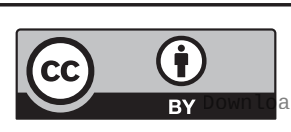

This work is licensed under a Creative Commons Attribution 4.0 International License.

ded from Bioscientifica.com at 04/26/2023 10:13:52AM 